\title{
The evolving gene regulatory landscape-a tinkerer of complex creatures
}

\author{
Geoffrey J. Faulkner ${ }^{1,2}$
}

Correspondence: faulknergj@gmail.

com

${ }^{1}$ Queensland Brain Institute,

University of Queensland, Brisbane, QLD 4072, Australia

${ }^{2}$ Mater Research Institute University of Queensland, TRI Building, Woolloongabba, QLD 4102, Australia

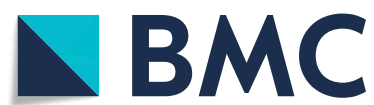

(c) The Author(s) 2021 Open Access This article is licensed under a Creative Commons Attribution 40 International License, which permits use, sharing, adaptation, distribution and reproduction in any medium or format, as long as you give appropriate credit to the original author(s) and the source, provide a link to the Creative Commons licence, and indicate if changes were made. The images or other third party material in this article are included in the article's Creative Commons licence, unless indicated otherwise in a credit line to the material. If material is not included in the article's Creative Commons licence and your intended use is not permitted by statutory regulation or exceeds the permitted use, you will need to obtain permission directly from the copyright holder. To view a copy of this licence, visit http//creativecommons.org/licenses/by/4.0/. The Creative Commons Public Domain Dedication waiver (http://creativecommons.org/publicdomain/zero/1.0/) applies to the data made available in this article, unless otherwise stated in a credit line to the data. 
the spatial organisation of chromatin is thought to influence the pairing of regulatory elements and protein-coding genes. This is elegantly shown by Furlan-Magaril et al. [7], again using the mouse liver circadian cycle, but here surveying chromosome conformation at high resolution to reveal the influence of differential promoter-enhancer interactions upon gene expression within topologically associated domains. Intriguingly, their results, as well as those of Huang et al. [8] obtained by studying androgen receptor-dependent enhancers in prostate cancer, suggest transcription factors can govern enhancer interactions with promoters. Transcription factors can also attract histone modifying complexes to enhancers. As an example of how perturbed histone modifications can lead to widespread aberrant enhancer activity, Di Giorgio et al. [9] find downregulation of the histone deacetylase HDAC4 in senescent cells leads to H3K27 hyperacetylation of enhancers linked to senescence-associated genes. Shifting focus to more direct regulatory pathways, Spiegel et al. [10] and Schwich et al. [11] explore the impact of proteins binding to G-quadruplex structures and alternative polyadenylation sites at gene $5^{\prime}$ and $3^{\prime}$ termini, respectively. Finally, Lee et al. [12] survey the regulatory element mutational landscape for thousands of whole cancer genomes and find significant associations between specific cancer subtypes and mutations in certain regulatory elements.

In the near future, more articles will be added to this Special Issue. Together, these works foster a more complete understanding of regulatory element function and evolution, as well as their impact on physiology and disease.

Author's contributions

The author read and approved the final manuscript.

\section{Declarations}

Competing interests

The author declares that he has no competing interests.

Published online: 08 July 2021

\section{References}

1. Jacob F. Evolution and tinkering. Science. 1977;196(4295):1161-6. https://doi.org/10.1126/science.860134.

2. Panigrahi A, O'Malley BW. Mechanisms of enhancer action: the known and the unknown. Genome Biol. 2021;22(1):108 https://doi.org/10.1186/s13059-021-02322-1.

3. McClintock B. The origin and behavior of mutable loci in maize. Proc Natl Acad Sci U S A. 1950;36(6):344-55. https://doi. org/10.1073/pnas.36.6.344.

4. Judd J, Sanderson H, Feschotte C. Evolution of mouse circadian enhancers from transposable elements. Genome Biol. 2021;22:193. https://doi.org/10.1186/s13059-021-02409-9.

5. Troskie R-L, Jafrani Y, Mercer TR, Ewing AD, Faulkner GJ, Cheetham SW. Long-read cDNA sequencing identifies functional pseudogenes in the human transcriptome. Genome Biol. 2021;22(1):146. https://doi.org/10.1186/s13059-02102369-0.

6. Gillard GB, Grønvold L, Røsæg LL, Holen MM, Monsen $\varnothing$, Koop BF, et al. Comparative regulomics supports pervasive selection on gene dosage following whole genome duplication. Genome Biol. 2021;22(1):103. https://doi.org/10.1186/ s13059-021-02323-0.

7. Furlan-Magaril M, Ando-Kuri M, Arzate-Mejía RG, Morf J, Cairns J, Román-Figueroa A, et al. The global and promotercentric 3D genome organization temporally resolved during a circadian cycle. Genome Biol. 2021;22(1):162. https://doi. org/10.1186/s13059-021-02374-3.

8. Huang C-CF, Lingadahalli S, Morova T, Ozturan D, Hu E, Yu IPL, et al. Functional mapping of androgen receptor enhancer activity. Genome Biol. 2021;22(1):149. https://doi.org/10.1186/s13059-021-02339-6.

9. Di Giorgio E, Paluvai H, Dalla E, Ranzino L, Renzini A, Moresi V, et al. HDAC4 degradation during senescence unleashes an epigenetic program driven by AP-1/p300 at selected enhancers and super-enhancers. Genome Biol. 2021;22(1):129. https://doi.org/10.1186/s13059-021-02340-z.

10. Spiegel J, Cuesta SM, Adhikari S, Hänsel-Hertsch R, Tannahill D, Balasubramanian S. G-quadruplexes are transcription factor binding hubs in human chromatin. Genome Biol. 2021;22(1):117. https://doi.org/10.1186/s13059-021-02324-z. 
11. Schwich OD, Blümel N, Keller M, Wegener M, Setty ST, Brunstein ME, et al. SRSF3 and SRSF7 modulate $3^{\prime} U T R$ length through suppression or activation of proximal polyadenylation sites and regulation of CFIm levels. Genome Biol. 2021; 22(1):82. https://doi.org/10.1186/s13059-021-02298-y.

12. Lee $C A, A b d-R a b b o D$, Reimand J. Functional and genetic determinants of mutation rate variability in regulatory elements of cancer genomes. Genome Biol. 2021;22(1):133. https://doi.org/10.1186/s13059-021-02318-x.

\section{Publisher's Note}

Springer Nature remains neutral with regard to jurisdictional claims in published maps and institutional affiliations. 